\title{
Family Support With Life Quality In Patients With Failure To Convert Heart
}

\author{
Enceng Herawati ${ }^{1}$ Aszrul Ab' ${ }^{2}$,Andi Baso Tombong3 \\ S1 Nursing Study Program, Stikes Panrita Husada Bulukumba, Indonesia ${ }^{1}$ \\ Departemen Community And Family Nursing , Stikes Panrita Husada Bulukumba, Indonesia ${ }^{2}$ \\ Departemen Nursing , RSUD H.Andi Sulthan Daeng Radja Indonesia ${ }^{3}$
}

Corresponding Autor: Encengherawati@gmail.com

\begin{abstract}
Patients with heart failure already have problems that will affect the quality of life, one of which can be influenced by family support. This study aims to determine the relationship of family support with quality of life in patients with congestive heart failure in H. Andi Sulthan Daeng Radja Hospital Bulukumba District. This study is an analytic observational study with a crosssectional approach. Sampling was done by consecutive sampling technique. The population in this study were 144 patients with congestive heart failure at H. Andi Sulthan Daeng Radja Regional General Hospital. The sample in this study were 48 people. The measuring instrument used is a questionnaire. Data analysis using the Chi-Square test. The results of the study showed that from 21 respondents who received good family support there were 16 (57.14) whose quality of life was poor and 5 (25\%) of good quality. And from 27 respondents who received family support in the poor category, there were 12 (42.85\%) of poor quality of life, and 15 $(75 \%)$ of good quality. Based on the results of the analysis of family support with quality of life using the Chi-Square statistical test obtained $\mathrm{p}=<0.027<0.5$ indicates that there is a relationship between family support and quality of life in congestive heart failure patients at $\mathrm{H}$. Andi Sulthan Daeng Radja Hospital Bulukumba District.
\end{abstract}

\section{Keyword : Family Support, Quality of Life, Congestive Heart Failure}

\section{INTRODUCTION}

Heart failure patients already have problems that will affect quality of life. Quality of life can be influenced by family support. Individuals who have a good quality of life will have good physical and spiritual health, and can carry out life in the community according to their respective roles. Quality of life can help determine certain problems that may arise in sufferers. Heart disease is one of the diseases that continues to increase in incidence and prevalence, according to the World Health Organization (WHO), cases of death in the world with the most causes are cardiovascular disease. 2012 WHO data on congestive heart failure showed that in 2008 there were 17 million or around $48 \%$ of total deaths due to congestive heart failure.

According to the Indonesian Ministry of Health in 2013, it showed that the prevalence of heart failure increased with age, there were $0.40 \%$ of Indonesia's population suffering from heart failure. The prevalence of heart failure based on the number of doctors diagnosed by $0.13 \%$, and symptoms of $0.3 \%$ of the data also shows 
that the mortality rate recorded $0.24 \%$ of them caused by heart disease. According to the Basic Health Research (Riskesdas) year (2013), in the province of South Sulawesi showed a prevalence of congestive heart failure at (0.5\%).

Based on preliminary data obtained by researchers on February 26, 2018 at H. Andi Sultan Daeng Radja Hospital in Bulukumba Regency for cases of congestive heart failure, in 2015 there were 62 patients, and in 2016 as many as 93 patients, and in 2017 patients with heart failure congestion increased by 114 patients.

Based on the results of Ervy Tamara's research (2014) about the relationship of family support and quality of life in patients at Arifin Achmad Regional Hospital in Riau Province, the results show that there is a relationship between family support and quality of life of patients in Arifin Achmad Regional Hospital in Riau Province. In line with research conducted by Erna Irawan (2017) There is a relationship between family support and quality of life in the city of Bandung, to overcome the gap between family support and quality of life it will plan programs related to family support or quality of life. The purpose of this study was to determine the relationship of family support with quality of life in patients with congestive heart failure in H. Andi Sulthan Daeng Radja Hospital Bulukumba

\section{MATERIALS AND METHODS}

Cross sectional research is a cause or risk variable and the effects or cases that occur in the research object are measured or collected simultaneously (at the same time) (Notoatmodjo, 2012). aims to determine the relationship between family support and the quality of life of congestive heart failure patients at H. Andi Sultan Daeng Radja Regional Hospital in Bulukumba. The population is the whole object of research or object to be studied (Notoatmodjo, 2012). The polls in this study were 114 patients suffering from congestive heart failure in H. Andi Sultan Daeng Radja District Hospital in Bulukumba district. Sampling using Consecutive Sampling technique is a method of sample selection which is done by selecting all individuals who meet and meet the selection criteria, until the desired number of samples is met (Dharma, 2015). The number of samples in this study were 48 respondents in H. Andi Sultan Daeng Radja Hospital in Bulukumba Regency. 
RESULTS

Tabel 1. Frequency Distribution Based on respondents' Characteristics

\begin{tabular}{|c|c|c|}
\hline Respondents' Characteristics & $n$ & Percentage (\%) \\
\hline Gender & 27 & 56,3 \\
\hline Male & 21 & 43,8 \\
\hline \multicolumn{3}{|l|}{ Female } \\
\hline Age & 2 & 4,2 \\
\hline$<30$ Year & 46 & 95,8 \\
\hline \multicolumn{3}{|l|}{$\geq 30$ Year } \\
\hline Last education & 6 & 12,5 \\
\hline SD & 8 & 16,7 \\
\hline SMP & 14 & 29,2 \\
\hline SMA & 3 & 6,3 \\
\hline D3 & 17 & 35,4 \\
\hline \multicolumn{3}{|l|}{ S1 } \\
\hline Amount & 48 & 100 \\
\hline
\end{tabular}

Based on Table 1 shows that most of the respondents were male, as many as 27 people with a percentage $(56.3 \%)$ and women as many as 21 respondents with a percentage $(43.8 \%)$. Most respondents were in the age group $\geq 30,46$ respondents with a percentage $(95.8 \%)$ and 2 respondents $(4.2 \%)$ aged $<30$ years. Respondents based on the highest educational background are the level of the last education S1 as many as 17 respondents (35.4\%), and the lowest level of education is D3 of 3 respondents (6.3\%).

Table 2. Distribution of Family Support Frequency and Quality of life in H. Andi Hospital Sulthan Daeng Radja Bulukumba Regency

\begin{tabular}{ccc}
\hline Varibel & n & Percentage (\%) \\
\hline Support Family & 20 & 41,7 \\
Good & 28 & 58,3 \\
Is Not Good & & 43,8 \\
Quality Of Life & & 56,3 \\
Good & 21 & \\
Is Not Good & 27 & 100 \\
\hline Amount & & \\
\hline
\end{tabular}

Based on Table 2 out of 48 respondents for family support there were 28 (58.3\%) that did not provide support, and 20 (41.7\%) provided good family support and for the quality of life of 48 respondents there were 27 (56.3\%) who have less quality of life, and 21 (43.8\%) good quality of life.

Table 3.Relationship between Family Support and Quality of Life in Patients with Congestive Heart Failure at H. Andi Sulthan Daeng Radja Hospital in Bulukumba Regency

\begin{tabular}{|c|c|c|c|c|}
\hline \multicolumn{3}{|c|}{ Quality of life } & \multirow[b]{2}{*}{ Total } & \multirow{3}{*}{ P Value } \\
\hline Family support & Good & Is Not God & & \\
\hline & $\%$ & $n$ & $\%$ & \\
\hline
\end{tabular}




\section{COMPRBHANSWE HEALT GHEE}

\begin{tabular}{lccccccc}
\hline Good & 5 & 25 & 16 & 57,14 & 21 & 43,75 & \\
\hline Is Not Good & 15 & 75 & 12 & 42,85 & 27 & 56,25 & 0,027 \\
\hline Amount & $\mathbf{2 0}$ & $\mathbf{1 0 0}$ & $\mathbf{2 8}$ & $\mathbf{1 0 0}$ & $\mathbf{4 8}$ & $\mathbf{1 0 0}$ & \\
\hline
\end{tabular}

Of the 21 respondents who received family support in the good category there were 16 (57.14) whose quality of life was not good, and 5 (25\%) good quality. And of the 27 respondents who received unfavorable family support there were 12 (42.85\%) of poor quality of life, and 15 (75\%) of good quality. Based on the results of the analysis using the Chi-Square test obtained significance value of 0.027 ( $p<0.05$ ), it can be concluded that "there is a Relationship of Family Support with Quality of Life in Patients with Congestive Heart Failure at H. Andi Sulthan Daeng Radja Hospital in Bulukumba Regency" .

\section{DISCUSSION}

In this study it was seen that there was a significant relationship between family support and quality of life in patients with Congestive Heart Failure at H. Andi Sulthan Daeng Radja Regional Hospital in Bulukumba. The relationship between Family Support and Quality of Life in Congestive Heart Failure Patients based on the results of the analysis using the Chi-Square statistical test obtained value $\rho=0.027<\alpha=0.5$ shows the relationship between Family Support and Quality of Life in Patients with Congestive Heart Failure at RSUD H Andi Sulthan Daeng Radja of Bulukumba Regency.

Based on the results of Ervy Tamara's research (2014) about the relationship of family support and quality of life in patients at Arifin Achmad Regional Hospital in Riau Province, the results show that there is a relationship between family support and quality of life of patients in Arifin Achmad Regional Hospital in Riau Province. In line with research conducted by Erna Irawan (2017) There is a relationship between family support and quality of life in the city of Bandung, to overcome the gap between family support and quality of life it will plan programs related to family support or quality of life.

The assumptions of researchers say that respondents who have good family support, the quality of life will be better seen from emotional support, appreciation, information, instrumental and the quality of life of respondents viewed from the physical, psychological, social and environmental dimensions. Whereas respondents who have poor family support are caused by lack of appreciation and instrumental support. Where the award support is the praise given by the family to sufferers and instrumental support, namely the support provided in the form of material provision 
including loans for money, food and services. And on the quality of life the lack of psychological domains and environmental domains, where the psychological domain is related to mental sufferers, how to think about daily appearances and the environmental domain that is the place of residence of individuals, where they interact with other individuals to carry out an activity of life.

\section{CONCLUSIONS}

Based on the results of the study above, it can be concluded that there is a relationship between family support and the quality of life of congestive heart failure in H. Andi Sulthan Daeng Radja Hospital, Bulukumba Regency. The results of the study hopefully can add to the library references and insight of Stikes Panrita Husada Bulukumba students about family support and quality of life in patients with congestive heart failure and are expected to be input to the hospital to improve family support and quality of life through education.

\section{REFERENCES}

Agustina, A., Afiyanti, Y., \& Ilmi, B. (2017). Pengalaman pasien gagal jantung kongestif dalam melaksanakan perawatan mandiri. Healty-Mu Vol. 1 No. 1 Juli .

Anita. (2016). Perawatan paliatif dan kualitas hidup penderita kanker. Kesehatan Volume VII, Nomor 3, November.

Azizah, R., \& Hartanti, R. D. (2016). Hubungan antara tingkat stress dengan kualitas hidup lansia hipertensi di wilayah kerja puskesmas wonopringgo pekalongan. The 4th Univesity Research Coloquium ISSN 2407-9189.

Bariroh, U., Setyawan, H., \& A, M. S. (2016). Kualitas hidup berdasarkan karakteristik pasien pasca stroke. Kesehatan masyarakat Volume 4, Nomor 4, Oktober .

Dharma, K. K. (2015). Metodologi Penelitian Keperawatan. Jakarta: Trans Info Media.

Effendy, N. (2012). Keperawatan kesehatan masarakat. Jakarta: Buku Kedokteran EGC.

Hardiyanti, D., Usman, S., \& Yusuf, R. (2016). Kemandirian keluarga dalam merawat anggota keluarga yang mengalami Skizofrenia. IImu keperawatan ISN : 23386371.

Harmoko. (2012). Asuhan keperawatan keluarga. Yogyakarta: Pustaka Pelajar.

Hutagalung, R. U., Susilaningsih, F. S., \& Mardiyah, A. (2014). Kualitas hidup pasien pascaintervensi koroner perkutan. Volume 2 Nomor 1 April .

Irawan, E., Hayati, S., \& Purwaningsih, D. (2017). Hubungan dukungan keluarga dengan kualitas hidup penderita kanker payudara . keperawatan BSI, Vol V No. 2 September. 
Karmila, Lestari, D. R., \& Herawati. (2016). Dukungan keluarga dengan kepatuhan minum obat pada pasien gangguan jiwa di wilayah kerja puskesmas Banjarbaru. Dunia keperawatan, Volume 2, Nomor 2, September .

Kasron. (2012). Gangguan sistem kardiovaskuler. Yogyakarta: nuhamedika.

Lukmanul hakim, \& Lismawati. (2017). Hubungan antara dukungan keluarga dengan kejadian depresi pada penderita penyakit ginjal kronik yang menjalani terapi hemodialisa di RSUD Dr.Dradjat Prawiranegara Serang. Ilmiah keperawatan indonesia Vol 1, No 1, .

Mailani, F., \& Andriani, R. F. (2017). Hubungan dukungan keluarga dengan kepatuhan diet pada pasien gagal ginjal kronik yang menjalani hemodialisis. Endurance Volume 2, Nomor 3.

Notoatmodjo, S. (2012). Metodologi penelitian kesehatan. Jakarta: Rineka Cipta.

Nur Rohmah, A. I., Purwaningsih, \& Bariyah, K. (2012). Kualitas hidup lanjut usia. Jurnal keperawatan volume 3 nomor 2 .

Permatasari, L. I., Lukman, M., \& Supriadi. (2014). Hubungan dukungan keluarga dan Self Efficacy dengan perawatan diri lansia hipertensi. Kesehatan komunitas indonesia Vol. 10. No. 2 September.

Samper, T. P., Pinontoan, O. R., \& Katuuk, M. E. (2017). Hubungan interaksi sosial dengan kualitas hidup lansiadi BPLU Senja Cerah Provinsi Sulawesi Utara. $e$ journal keperawatan (e-KP) Volume 5 Nomor 1, Februari.

Sefrina, F., \& Latipun. (2016). Hubungan dukungan keluarga dan keberfungsian sosial pada pasien Skizofrenia rawat jalan. Imiah Psikologi Terapan, Vol 04, No. 02, Agustus.

Sujarweni, V. W. (2014). Metodologi penelitian keperawatan. Yogyakarta: Gava medika.

Suratinoyo, I., Rottie, J. V., \& Massi, G. N. (2016). Hubungan tingkat kecemasan dengan mekanisme koping pada pasien gagal jantung kongestif diruangan CVBC (cardio vaskuler brain centre) lantai III di RSUP. PROF. DR. R. D. Kandou Manado. ejournal keperawatan (e-kp) Volume 4 Nomor1, Mei .

Susilawati, D. (2013). Hubungan antara dukungan keluarga dengan tingkat kecemasan penderita kanker serviks paliatif DI RSUP DR Sardjito Yogyakarta. Jurnal Keperawatan, Volume 4, Nomor 2.

Syamsuddin. (2015). Pedoman Praktis Metodologi Penelitian Internal. Wade group: Indonesia.

Tamara, E., Bayhakki, \& Nauli, F. A. (2014). Hubungan antara dukungan keluarga dengan kualitas hidup pasien diabetes mellitus tipe II di RSUD Arifin Achmad Provinsi Riau. JOM PSIK Vol.1 No.2 Oktober .

Tamuwun, C. F., Panda, A. L., \& Rampengan, S. H. (2016). Gambaran pasien gagal jantung dengan penyakit hipertensi yang menjalani rawat inap di RSUP Prof. Dr. R. D. 
Kandou Manado periode September- November. e-Clinic (eCI) Volume 4, Nomor 2, Juli-Desember .

Ufara, A., Purnamasari, E., \& Usniah. (2016). Hubungan kepatuhan minum obat dengan kejadian rawat inap ulang pada pasien gagal jantung kongestif di RSU Kabupaten Tanggerang. JKTF Edisi Nomor 2, Januari .

Utami, R. S., \& Raudatussalamah. (2016). Hubungan dukungan sosial keluarga dengan kepatuhan berobat penderita hipertensi di puskesmas Tualang. Psikologi, Volume 12, Nomor 1, Juni.

Wahyuni, A., \& Kurnia, O. S. (2014). Hubungan self care dan motivasi dengan kualitas hidup pasien gagal jantung. Volume 2 Nomor 2 Agustus .

Widyanto, F. C. (2014). Keperawatan Komunitas. Yogyakarta: Medical Book.

Yasmin, A. M. (2017). Hubungan antara dukungan keluarga dengan kecemasan pada remaja penginap HIV/AIDS (pada klinik VCT Wahab Sjahranie Samarinda). PSIKOBORNEO, Volume 5, Nomor 3, . 